\title{
Luftemboli via intraossøs nål?
}

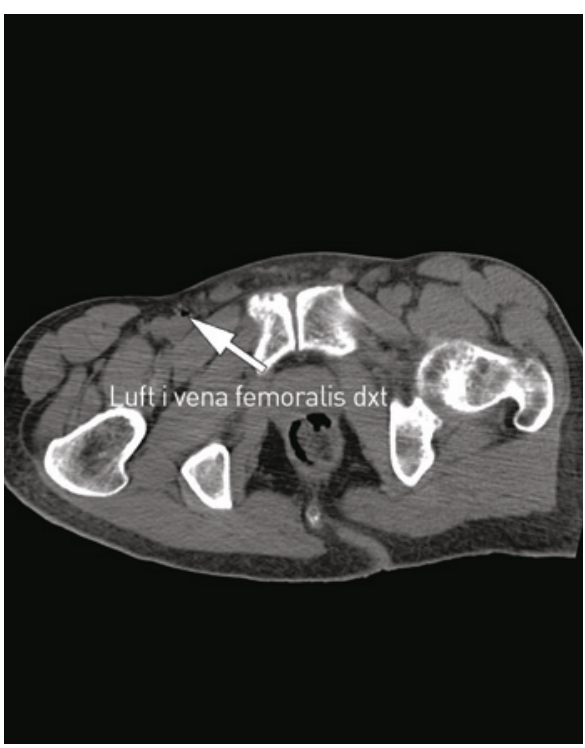

En mann i 60-årene med flere kjente alvorlige diagnoser ble funnet livløs av hjemmesykepleier, og hjerte-lunge-redning ble iverksatt. Da ambulansepersonell kom til, ble det registrert uttalt sinusbradykardi. Det ble lagt inn intraossøs nål i høyre os tibia. Pasienten ble resuscitert i ca. 10 minutter og lagt i sjokkleie, men forble alvorlig hypotensiv med blodtrykk rundt 40/20 mm Hg.

På sykehuset fikk han flere venekanyler i overekstremitetene. Den intraossøse nålen ble fjernet etter å ha vært åpen rundt en halvtime mens pasienten lå i sjokkleie. CT-undersøkelse av thorax, abdomen og bekken uten intravenøs kontrast tatt kort tid etter ankomst viste luft i høyre vena femoralis, vena cava inferior og venstre nyrevene. Sikker årsak til hjertestans ble ikke funnet, og pasienten døde etter et kort intensivopphold.

Da det $i$ akutte situasjoner kan være vanskelig å få lagt intravenøs tilgang, brukes intraossøs metode i økende grad, særlig i ambulansetjenesten og hos kritisk syke barn (1). Det er beskrevet noen få tilfeller med luft i cerebrale arterier fra intraossøs nål ved gjenopplivning av barn, og derfor er det viktig å kjenne til faren for luftemboli (2). Vi mener det er sannsynlig at luften hos pasienten beskrevet over kom inn via den intraossøse nålen.

En årsak til luftemboli kan være utilsiktet infusjon av luft fra infusjonssettet, særlig om det brukes overtrykk. Det er ingen mistanke
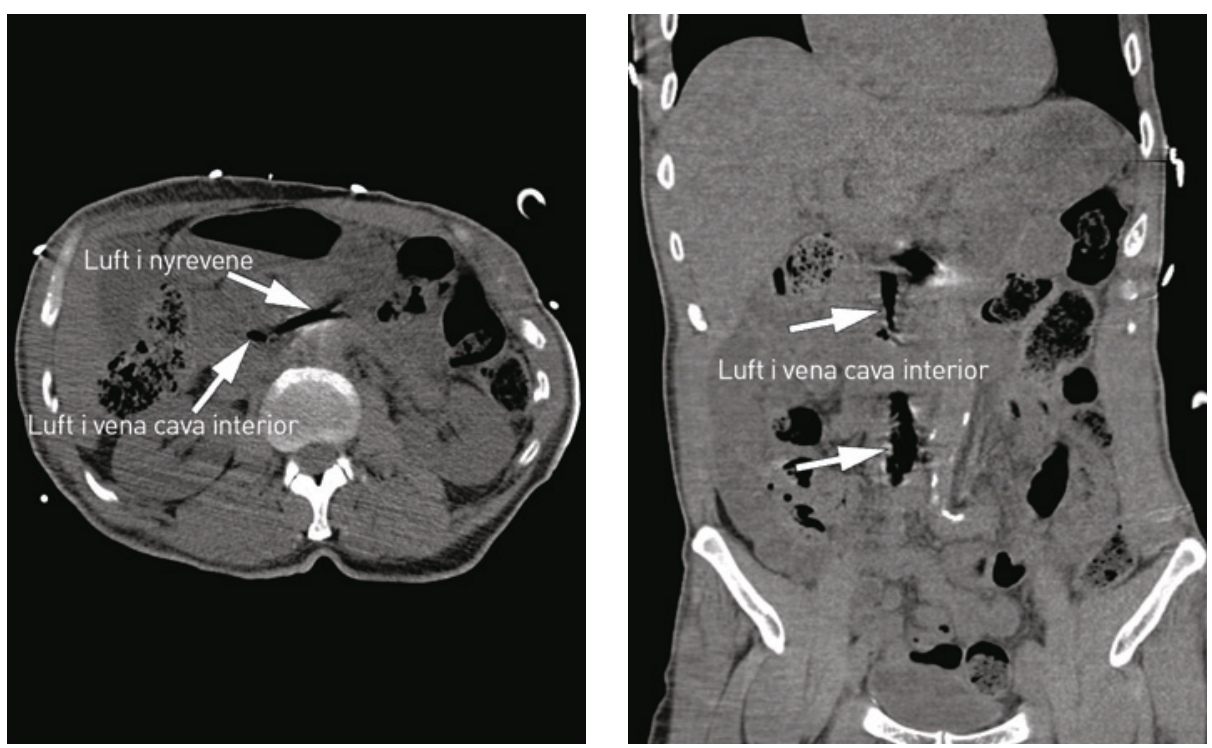

om at luft ble infundert hos denne pasienten, da det ikke ble brukt overtrykk på venekanylene, og infusjonssettet ble fullstendig fylt. En annen mulig årsak er at luften kan suges inn via en åpen intraossøs nål som ligger høyere enn hjertet. I et dyreforsøk fant man at de intraossøse trykkene var ca. $22 \%$ av middelarterietrykket. Trykkurven hadde arteriekurvens form, var respirasjonsavhengig og falt med synkende middelarterietrykk (3). Vi mener derfor at det er holdepunkter for at det intraossøse trykket kan bli negativt ved et lavt middelarterietrykk og med hevet tibia (sjokkleie). Da vil trolig luft kunne suges inn som ved et åpent sentralt venekateter.

Pasientens pårørende har gitt samtykke til at artikkelen blir publisert.

\section{Robin Breivik Ellingsen \\ roelling@gmail.com}

Diagnostisk klinikk

\section{Farid Khan Baloch}

Akuttmedisinsk klinikk

Nordlandssykehuset Bodø

Erik Waage Nielsen

Akuttmedisinsk klinikk

Nordlandssykehuset Bodø og

Institutt for klinisk medisin

Universitetet i Troms $\varnothing$ og

Profesjonshøgskolen

Universitetet i Nordland
Robin Breivik Ellingsen (f. 1986) er lege i spesialisering i radiologi.

Forfatter har fylt ut ICMJE-skjemaet og oppgir ingen interessekonflikter.

Farid Khan Baloch (f. 1979) er lege i spesialisering i anestesiologi.

Forfatter har fylt ut ICMJE-skjemaet og oppgir ingen interessekonflikter.

Erik Waage Nielsen (f. 1956) er professor, overlege og spesialist i anestesiologi og har europeisk intensiveksamen (EDIC 1\&2).

Forfatter har fylt ut ICMJE-skjemaet og oppgir ingen interessekonflikter.

Litteratur

1. Dev SP, Stefan RA, Saun T et al. Videos in clinical medicine. Insertion of an intraosseous needle in adults. N Engl J Med 2014: 370: e35.

2. van Rijn RR, Knoester H, Maes A et al. Cerebral arterial air embolism in a child after intraosseous infusion. Emerg Radiol 2008; 15: 259-62.

3. Frascone RJ, Salzman JG, Adams AB et al. Evaluation of intraosseous pressure in a hypovolemic animal model. J Surg Res 2015; 193: 383-90.

Mottatt 3.6. 2015, første revisjon innsendt 20.9. 2015, godkjent 6.11. 2015. Redaktør: Liv-Ellen Vangsnes. 